\title{
COMPARATIVE STUDY OF INTRAVENOUS DEXMEDETOMIDINE PLUS INTRATHECAL BUPIVACAINE VS INTRATHECAL BUPIVACAINE ALONE FOR PROLONGATION OF SPINAL ANALGESIA
}

\author{
H. L. Rani' ${ }^{1}$ I. Upendranath ${ }^{2}$
}

${ }^{1}$ Associate Professor, Department of Anaesthesia, Osmania Medical College, Hyderabad, Telangana.

${ }^{2}$ Associate Professor, Department of Anaesthesia, Dr. V. R. K. Teaching Hospital \& Research Centre, Aziz Nagar, Hyderabad. Telangana.

ABSTRACT: BACKGROUND: The prolongation of spinal anaesthesia by using clonidine through the oral, intravenous and spinal route has been known. The new alpha-2 agonist, dexmedetomidine has been proved to prolong the spinal anaesthesia through the intrathecal route. We hypothesized that dexmedetomidine when administered intravenously following spinal block also prolongs spinal analgesia. A placebo controlled randomized controlled trial study was done.

METHODOLOGY: 50 Patients were randomly allocated into two equal groups group D and group C. Both group received spinal hyperbaric bupivacaine $15 \mathrm{mg}$ intrathecally. Patients in group D received intravenously a loading dose of $1 \mathrm{mcg} / \mathrm{kg}$ dexmedetomidine over $10 \mathrm{~min}$ followed by C maintenance dose of $0.5 \mathrm{mcg} / \mathrm{kg} / \mathrm{hr}$ till the end of surgery. Patients in group C (The control group) received normal saline. The regression times to reach S1 sensory level and bromage 0 motor scale, hemodynamic changes and the level of sedation were recorded.

RESULTS: The duration of sensory block was longer in intravenous dexmedetomidine group compared with control group (264.32 $\pm 15.3 \mathrm{~min}$ vs $164.2 \pm 13.12 \mathrm{~min}, \mathrm{p}$ 0.001). The duration of motor block was longer in dexmedetomidine group than control group (198.8 \pm 16.9 min vs $135.8 \pm 12.38 \mathrm{~min}, \mathrm{p} 0.001)$

CONCLUSION: Intravenous dexmedetomidine administration prolonged the sensory and motor blocks of bupivacaine spinal analgesia with good sedation effect and hemodynamic stability. The incidence of bradycardia is significantly high when intravenous dexmedetomidine is used as an adjuvant to bupivacaine spinal anaesthesia. Dexmedetomidine induced bradycardia and hypotension can be easily managed with atropine and mephentermine respectively. Dexmedetomidine provides excellent sedation and postoperative analgesia.

KEYWORDS: Dexmedetomidine, Hyperbaric Bupivaine, Intrathecal, Ramsay Sedation Score, Spinal Anaesthesia.

HOW TO CITE THIS ARTICLE: H. L. Rani, I. Upendranath. "Comparative Study of Intravenous Dexmedetomidine Plus Intrathecal Bupivacaine vs Intrathecal Bupivacaine Alone for Prolongation of Spinal Analgesia." Journal of Evolution of Medical and Dental Sciences 2015; Vol. 4, Issue 94, November 23; Page: 15952-15959, DOI: 10.14260/jemds/2015/2324.

INTRODUCTION: Quincke in 1891 demonstrated a safe, predictable means of performing lumbar puncture. Bupivacaine, a pipecoloxylidide derivative synthesized in 1957 by Ekenstam and introduced in clinical practice in 1963 is widely used for spinal anaesthesia. It is a racemic mixture of $\mathrm{D}$ and $\mathrm{L}$ isomers and is relatively more cardiotoxic compared to other local anaesthetics. ${ }^{1,4}$ Spinal anaesthesia is a commonly used technique in anaesthetic practice for gynaecological, lower abdominal, pelvic, and lower limb surgeries.

Bupivacaine is appropriate for procedures lasting for 2 to 2.5 hours. If the duration of surgery prolongs it may have to be converted into general anaesthesia or supplemented with an intravenous anaesthetic agent.

To overcome this adjuvants like epinephrine, phenylephrine, adenosine, magnesium sulphate, sodium bicarbonate, neostigmine and alpha- 2 agonists like clonidine, dexmedetomidine have been used intrathecally. ${ }^{5}$

Financial or Other, Competing Interest: None.

Submission 01-11-2015, Peer Review 02-11-2015,

Acceptance 13-11-2015, Published 21-11-2015.

Corresponding Author:

Dr. H. L. Rani,

Department of Anaesthesia,

Ho. No: 35-81/6,

Sapthagiri Colony, Neredmet X Road, Sainikpuri,

Hyderabad-500094,

Telangana.

E-mail: ranisarvepalli9@gmail.com

DOI:10.14260/jemds/2015/2324.
CONTEXT: Clonidine and dexmedetomidine are also used intravenously to prolong the duration of the spinal anaesthesia. ${ }^{2,11}$

Apart from sedation and analgesia, they also decrease sympathetic tone and decrease the stress responses to surgery and anaesthesia. They produce sedation and anxiolysis by binding to presynaptic alpha- 2 receptors in locus ceruleus. ${ }^{11}$ Postsynaptic activation in CNS inhibits sympathetic activity thus decreasing heart rate and blood pressure.

Dexmedetomdine is a more suitable adjuvant to spinal anaesthesia compared to clonidine as it has more sedative and analgesic effects due to its more selective alpha-2A receptor agonist activity. Few studies have shown the efficacy of intravenous dexmedetomidine in prolonging prilocaine/bupivacaine/ropivacaine spinal anaesthesia in addition to providing good sedation and postoperative analgesia.

Different drugs like epinephrine, phenylephrine, adenosine, magnesium sulphate, sodium bicarbonate, neostigmine and alpha-2 agonists like clonidine, dexmedetomidine have been used as adjuvants to local anaesthetics to prolong the duration of spinal anaesthesia. Among them clonindine an alpha-2 agonist is widely used by oral, intrathecal and intravenous routes as an adjuvant to prolong spinal anaesthesia. Recent studies have shown the efficacy of both intrathecal and intravenous dexmedetomidine in prolonging spinal anaesthesia. 
MATERIAL AND METHODS: After taking informed consent at Osmania General Hospital/Osmania Medical College, Hyderabad over a period of 12 months and approval from the hospital ethical committee, a comparative study was carried out on 50 adult patients.

AIM: To evaluate the effects of I.V. dexmedetomidine on the duration of subarachnoid block, haemodynamic changes and sedation in patients undergoing surgeries under spinal anaesthesia with $0.5 \%$ of hyperbaric bupivacaine. Patients were randomly divided on an alternative basis into 2 groups of 25 each. Group "D" - received dexmedetomidine IV bolus $(1 \mathrm{mcg} / \mathrm{kg}$ over 10 minutes) followed by infusion $(0.5 \mathrm{mcg} / \mathrm{kg} / \mathrm{hr})$ Group "C" - received normal saline $0.9 \%$ in 10 minutes, the same calculated volume as in group D. A placebocontrolled randomized controlled trial.

\section{Inclusion Criteria:}

1. ASA grade 1 and 2 patients.

2. Age group of 18 - 50 years.

3. Patients giving valid informed consent.

4. Those patients scheduled to undergo elective orthopedic lower extremity surgery under subarachnoid block.

\section{Exclusion Criteria:}

1. Patient refusal.

2. Patients with gross spinal abnormality, localized skin sepsis, haemorrhagic diathesis, or neurological involvement/diseases.

3. Head injury cases.

4. Patient receiving alpha-2 adrenergic receptor antagonists, calcium channel blockers, ACE inhibitors, having dysarrhythmias on ECG, body weight more than $120 \mathrm{kgs}$.

Pre-anaesthetic check up was carried out preoperatively with a detailed history, general examination and systemic examination, airway assessment, spinal column examination were done.

The following laboratory examination were done in selected patients:

- Haemoglobin.

- Urine analysis.

- Blood sugar.

- Blood urea.

- Serum creatinine.

- Coagulation profile.

- Blood grouping and Rh typing.

- ECG for patients over 40 years of age.

- Chest x-ray.

PROCEDURE: Patient was shifted to the OT table, IV access was obtained on the forearm with $18 \mathrm{G} \mathrm{IV}$ canula and lactated ringer solution $10 \mathrm{ml} / \mathrm{kg}$ was infused before the block. The monitors connected to the patient included non-invasive blood pressure, ECG, HR and pulse oximeter. Under strict aseptic precautions lumbar puncture was performed with disposable Quincke's spinal needle (25G) at the L3-L4 space.

The The spinal injection rate of Hyperbaric bupivacine $0.5 \%$ was $1 \mathrm{ml} / 3-4$ seconds in all patients. Hyperbaric $0.5 \%$ bupivacine, $15 \mathrm{mg}(3 \mathrm{ml})$ was injected intrathecally in all patients. A $50 \mathrm{cc}$ syringe was prepared with either normal saline or dexmedetomidine, diluted with normal saline in a concentration of $4 \mathrm{mcg} / \mathrm{ml}$. Immediately, after spinal analgesia patients were laid back to supine position. Level of sensory anesthesia was varies from T6-T10.

Patients allocated to group D received intravenously through the intravenous infusion pump a loading dose of $1 \mathrm{mcg} / \mathrm{kg} / \mathrm{hr}$ dexmedetomidine over 10 minutes and a maintenance dose of $0.5 \mathrm{mcg} / \mathrm{kg} / \mathrm{hr}$ till the end of surgery.

Patients in group $\mathrm{C}$ received in $10 \mathrm{~min}$ the same calculated volume normal saline of loading and maintenance dose as in group D. Patients were monitored continuously using NIBP, pulse oxymeter and ECG.

After spinal anaesthesia, oxygen (6lts/min) by face mask was given fluid therapy was maintained with lactated ringer solution infused according to patients haemodynamics volume status. After giving spinal anaesthesia the dexmedetomidine (group D) received Dexmedetomidine $1 \mathrm{mcg} / \mathrm{kg}$ for 10 minutes using burette set and then $1 \mathrm{mcg} / \mathrm{kg} / \mathrm{hr}$ by continuous infusion till end of the surgery.

\section{Vital Parameters:}

HR, NIBP, SPO2, RR, ECG at 1, 2, 5, 10, 15, 20, 25, 30, 45, 60, 90 ........240mins.

Assessment of Sensory Blockade: The onset of sensory block was tested by pin prick method using a hypodermic needle. The time of onset was taken from the time of injection of drug into Sub Arachnoid Space to loss of pin prick sensation.

The highest level of sensory block and time was noted. The time for 2 dermatomal segment regression of sensory level was noted. The duration of sensory blockade was taken as time from onset to time to return of pinprick sensation to S1 (Heel) dermatomal area.

Assessment of Motor Blockade: Was assessed by modified Bromage scale. The duration of motor block was taken from time of injection to complete regression of motor block. (Ability to lift the extended leg) (Br 0).

\section{Assessment of Sedation:}

The level of sedation was evaluated intraoperatively and postoperatively every 15 minutes using Ramsey level of sedation score.

1. Patient anxious, agitated, or restless.

2. Patient cooperative, oriented.

3. Patient responds to commands.

4. Asleep, but with brisk response to light glabella tap or loud auditory stimulus.

5. Asleep, sluggish response to light glabellar tap or loud auditory stimulus.

6. Asleep, no response.

\begin{tabular}{|c|c|c|c|}
\hline & Group C & Group D & $\begin{array}{c}\text { P } \\
\text { value }\end{array}$ \\
\hline $\begin{array}{c}\text { Duration for 2 } \\
\text { dermatomal } \\
\text { regression }\end{array}$ & $95.6 \pm 9.61$ & $128.4 \pm 9.54$ & $<0.001$ \\
\hline $\begin{array}{c}\text { Duration of } \\
\text { sensory blockade } \\
\text { upto S1 segment }\end{array}$ & $164.2 \pm 13.12$ & $264.32 \pm 15.3$ & $<0.001$ \\
\hline \multicolumn{3}{|c|}{ Table 1. Duration of Sensory Blockade } \\
and 2 Segment Regression
\end{tabular}


The duration of sensory blockade upto S1 and duration for 2segment regression of sensory blockade were significantly prolonged in dexmedetomidine group as compared to control group ( $p$ value $<0.001$ ). The sensory blockade and the 2 segmental regression in both the groups is summarized in Table 1.

Duration of Motor Blockade: The duration of motor block regression to modified Bromage scale 0 were significantly prolonged in dexmedetomidine group as compared to control group ( $\mathrm{p}$ value $<0.001$ )

The duration of motor block in both the groups is summarized in Table 2.

\begin{tabular}{|c|c|c|}
\hline $\begin{array}{c}\text { Total Duration of Motor } \\
\text { Block (In min) }\end{array}$ & Group C & Group D \\
\hline Range & $110-160$ & $160-230$ \\
Mean & 135.8 & 198.8 \\
SD & 12.38 & 16.9 \\
Value & $135.8 \pm 12.38$ & $198.8 \pm 16.9$ \\
\hline p value & \multicolumn{2}{|c|}{$<0.001$} \\
\hline \multicolumn{2}{|c|}{ Table 2: Duration of Motor Block in Both Groups } \\
\hline
\end{tabular}

Hemodynamic Data: The hemodynamic parameters taken into consideration were the Heart Rate, Blood Pressure (Systolic, Diastolic and Mean). The results obtained are given below as graphs and tables, which compare the mean values of the parameters before and after SAB. The results are compared within each group and between the both groups before and after SAB.

\section{A) Heart Rate:}

\begin{tabular}{|c|c|c|c|c|}
\hline & \multicolumn{2}{|c|}{$\begin{array}{c}\text { Heart Rate (bpm) } \\
\text { (Mean SD) }\end{array}$} & \multirow{2}{*}{$P$ value } \\
\hline & & Group D & Group C & \\
\hline \multicolumn{2}{|c|}{ Baseline 0 min } & $78.4 \pm 7.6$ & $79.6 \pm 7.1$ & 0.5667 \\
\hline \multirow{8}{*}{$\begin{array}{c}\text { Duration } \\
\text { of SAB }\end{array}$} & 2 mins & $76.4 \pm 9.0$ & $74.9 \pm 7.0$ & 0.5138 \\
\hline & $5 \mathrm{mins}$ & $73.2 \pm 7.5$ & $73.48 \pm 6.9$ & 0.8913 \\
\hline & $\begin{array}{c}10 \\
\text { mins }\end{array}$ & $65.36 \pm 6.4$ & $70.8 \pm 7.2$ & 0.0069 \\
\hline & $\begin{array}{c}15 \\
\text { mins }\end{array}$ & $63.9 \pm 4.5$ & $71.48 \pm 7.1$ & $<0.0001$ \\
\hline & $\begin{array}{c}20 \\
\text { mins }\end{array}$ & $63.7 \pm 6.04$ & $71.2 \pm 7.1$ & $<0.0001$ \\
\hline & $\begin{array}{c}25 \\
\text { mins }\end{array}$ & $61.8 \pm 7.1$ & $70.56 \pm 9.3$ & $<0.0001$ \\
\hline & $\begin{array}{c}30 \\
\text { mins }\end{array}$ & $60.7 \pm 8.87$ & $71.1 \pm 8.17$ & $<0.0001$ \\
\hline & $\begin{array}{c}45 \\
\text { mins }\end{array}$ & $61.3 \pm 12.8$ & $70.3 \pm 7.77$ & $<0.0001$ \\
\hline
\end{tabular}

\begin{tabular}{|c|c|c|c|c|}
\hline & $\begin{array}{c}60 \\
\text { mins }\end{array}$ & $61.3 \pm 8.54$ & $70.9 \pm 7.67$ & $<0.0001$ \\
\cline { 2 - 5 } & $\begin{array}{c}75 \\
\text { mins }\end{array}$ & $62.2 \pm 5.8$ & $72 \pm 7.3$ & $<0.0001$ \\
\cline { 2 - 5 } $\begin{array}{c}90 \\
\text { mins }\end{array}$ & $63.7 \pm 5.16$ & $72.7 \pm 7.3$ & $<0.0001$ \\
\cline { 2 - 5 } $\begin{array}{c}120 \\
\text { mins }\end{array}$ & $63.5 \pm 2.95$ & $73.5 \pm 6.28$ & $<0.0001$ \\
\hline $\begin{array}{c}150 \\
\text { mins }\end{array}$ & $63.5 \pm 3.09$ & $73.3 \pm 5.9$ & $<0.0001$ \\
\hline $\begin{array}{c}180 \\
\text { mins }\end{array}$ & $64.9 \pm 4.27$ & $75.6 \pm 7.9$ & $<0.0001$ \\
\hline $\begin{array}{c}210 \\
\text { mins }\end{array}$ & $66.6 \pm 4.61$ & $76 \pm 6.7$ & $<0.0001$ \\
\hline $\begin{array}{c}240 \\
\text { mins }\end{array}$ & $68.1 \pm 5.0$ & $76 \pm 6$ & $<0.0001$ \\
\hline
\end{tabular}

Between the Groups: The average heart rate was significantly lower in dexmedetomidine group $(64.25 \pm 5.88)$ as compared to control group $(73.14 \pm 7.21)$ ( $\mathrm{p}$ value $<0.001$ ).

Significantly, higher number of patients in dexmedetomidine group (5/25-20\%) had transient intraoperative heart rate $<50 / \mathrm{mt}$ as compared to control group (1/25-4\%) (p value-0.004). Atropine was required higher in dexmedetomidine group $(4 / 25-16 \%)$ as compared to control group C (1/25-4\%) (p value-0.003).

\begin{tabular}{|c|c|c|c|}
\hline & Group C & Group D & P value \\
\hline $\begin{array}{c}\text { No(\%) of patients } \\
\text { with HR <60 }\end{array}$ & $6(24 \%)$ & $17(68 \%)$ & 0.001 \\
\hline $\begin{array}{c}\text { No (\%) of patients } \\
\text { with HR < 50 }\end{array}$ & $1(4 \%)$ & $5(20 \%)$ & 0.004 \\
\hline $\begin{array}{c}\text { No (\%) of patients } \\
\text { required Atropine }\end{array}$ & $1(4 \%)$ & $4(16 \%)$ & 0.003 \\
\hline \multicolumn{3}{|c|}{$\begin{array}{c}\text { Comparision of Bradycardia and Atropine } \\
\text { Requirement in Both the Groups }\end{array}$} \\
\hline
\end{tabular}

\section{Systolic Blood Pressure:}

Between the Groups: The average intraoperative SBP was lower in dexmedetomidine group $(104.62 \pm 7.95)$ as compared to control group $(109.25 \pm 4.96)$ ( $p$ value-0.131). Lowest intraoperative SBP was significantly lower in dexmedetomidine group $(92.52 \pm 5.37)$ as compared to control group $(96.96 \pm 5.52)$ (p value 0.005$)$. Average postoperative SBP was significantly lower in group D (104.2 \pm 7.9$)$ as compared to group C $(113 . \pm 4.3)$ ( $p$ value 0.0001$)$. There was no significant difference in the intraoperative requirement of mephentermine in both the groups. Group D (4/25-16\%) as compared to group C (2/25-8\%) (P value 0.525$)$. 


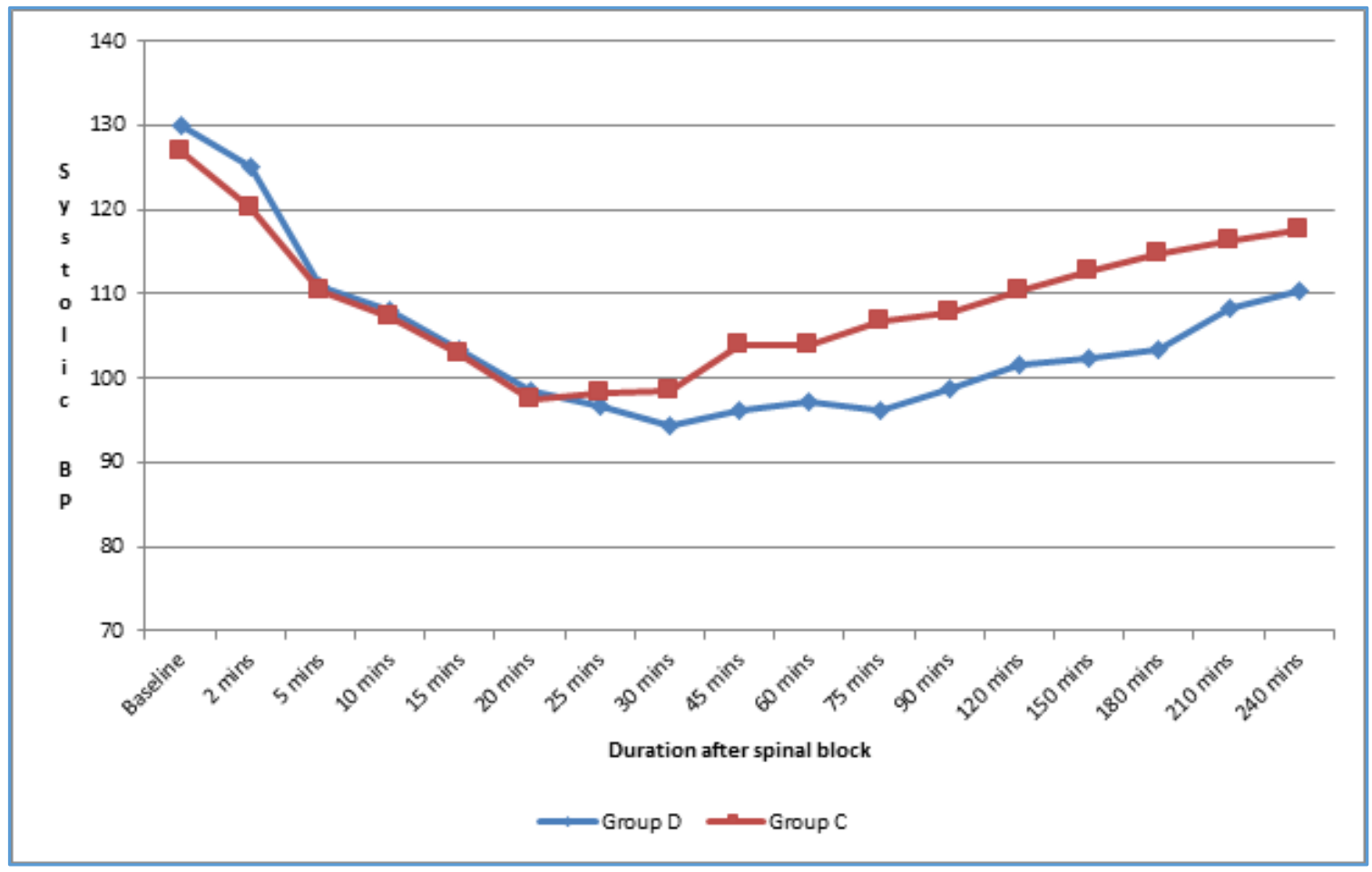

Fig. 1: Line Diagram Comparing the Systolic Blood Pressure in Both the Groups.

There was no significant difference in the intraoperative requirement of total IV fluids between dexmedetomidine and control group $(1752 \pm 418.69 v s 1592 \pm 317.437)$ ( $p$ value $0.134)$.

\begin{tabular}{|c|c|c|c|}
\hline & Group C & Group D & $\begin{array}{c}\text { P } \\
\text { value }\end{array}$ \\
\hline Mephentermine & 2 & 4 & 0.525 \\
\hline IV Fluids & $\begin{array}{c}1592 \\
\pm 317.437\end{array}$ & $\begin{array}{l}1752 \\
\pm 418.69\end{array}$ & 0.134 \\
\hline \multicolumn{3}{|c|}{ Comparision of Mephentermine Requirement } \\
and IV Fluids in Both Groups \\
\hline
\end{tabular}

\section{Diastolic Blood Pressure:}

Between the Groups: The average intraoperative DBP was lower in group D $(63.57 \pm 6.066)$ as compared to control group $(66.33 \pm 4.13)$ ( $\mathrm{p}$ value 0.34$)$.

Lowest intraoperative DBP was significantly lower in group D $(58.48 \pm 5.97)$ as compared to group $C(63.9 \pm 4.2)$ (p value $0.0005)$. Average postoperative DBP was significantly lower in group D (61.5 \pm 5.69$)$ as compared to group C $(67.6 \pm 4.21)$ (p value 0.0001$)$.

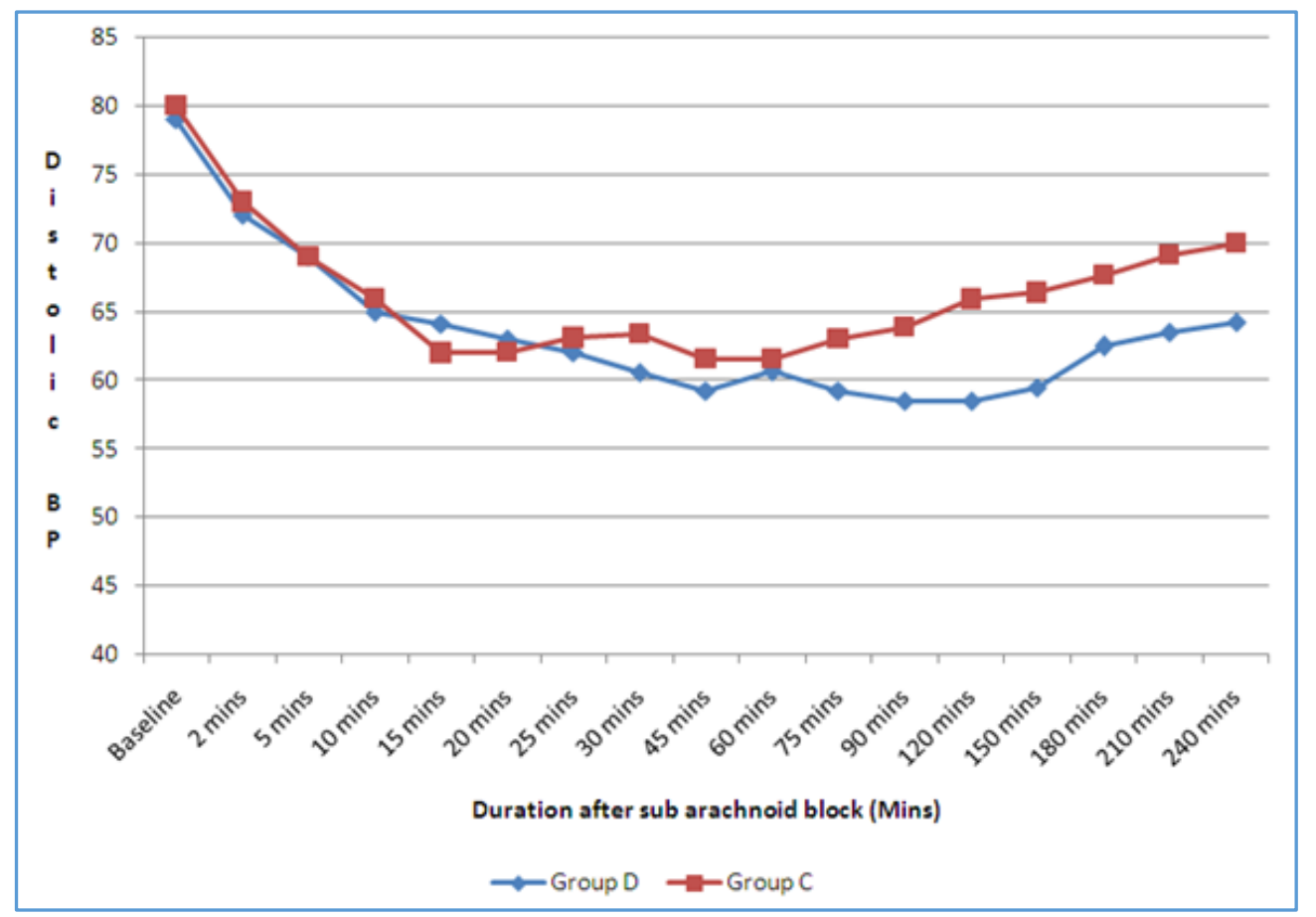

Fig. 2: Line Diagram Comparing the Diastolic Blood Pressure in Both the Groups 
The intraoperative MAP after spinal blockade was lower in group D $(76.94 \pm 5.99)$ as compared to group C (80.4 \pm 3.84$)$ ( $p$ value 0.0188).

Lowest intraoperative average MAP in group D (70.4 \pm 5.15$)$ as compared to group C $(73.2 \pm 4.29)$ (p value 0.0421). Average

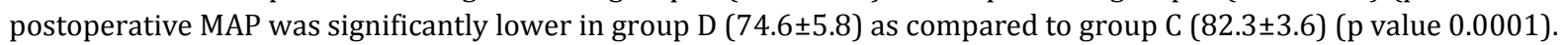

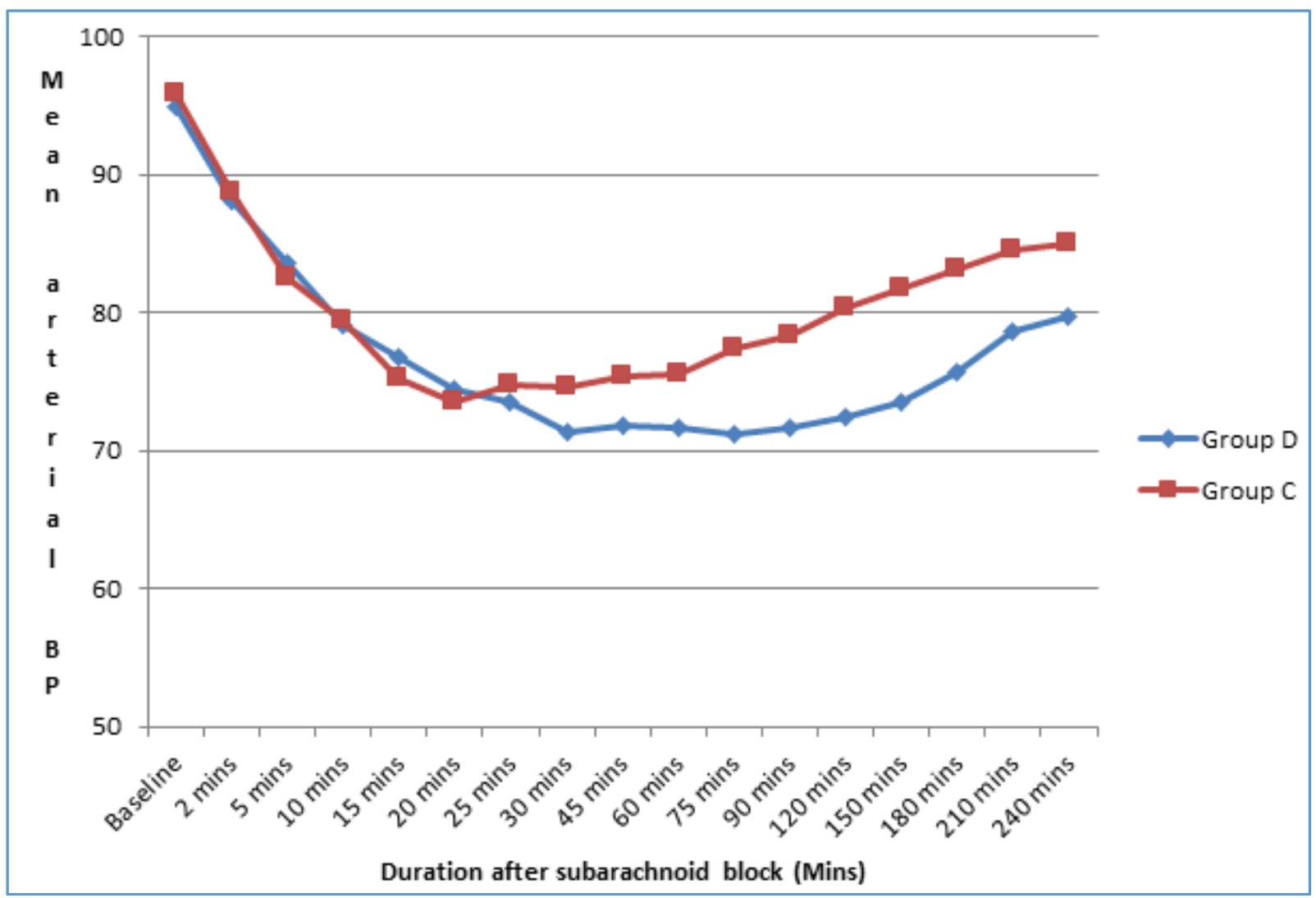

Fig. 3: Line Diagram Comparing the Mean Arterial Pressure in Both the Groups

\section{Oxygen Saturation -SPO2}

There was no significant difference in SPO2 levels between both the groups during surgery and in the postoperative period as shown in Figure 4.

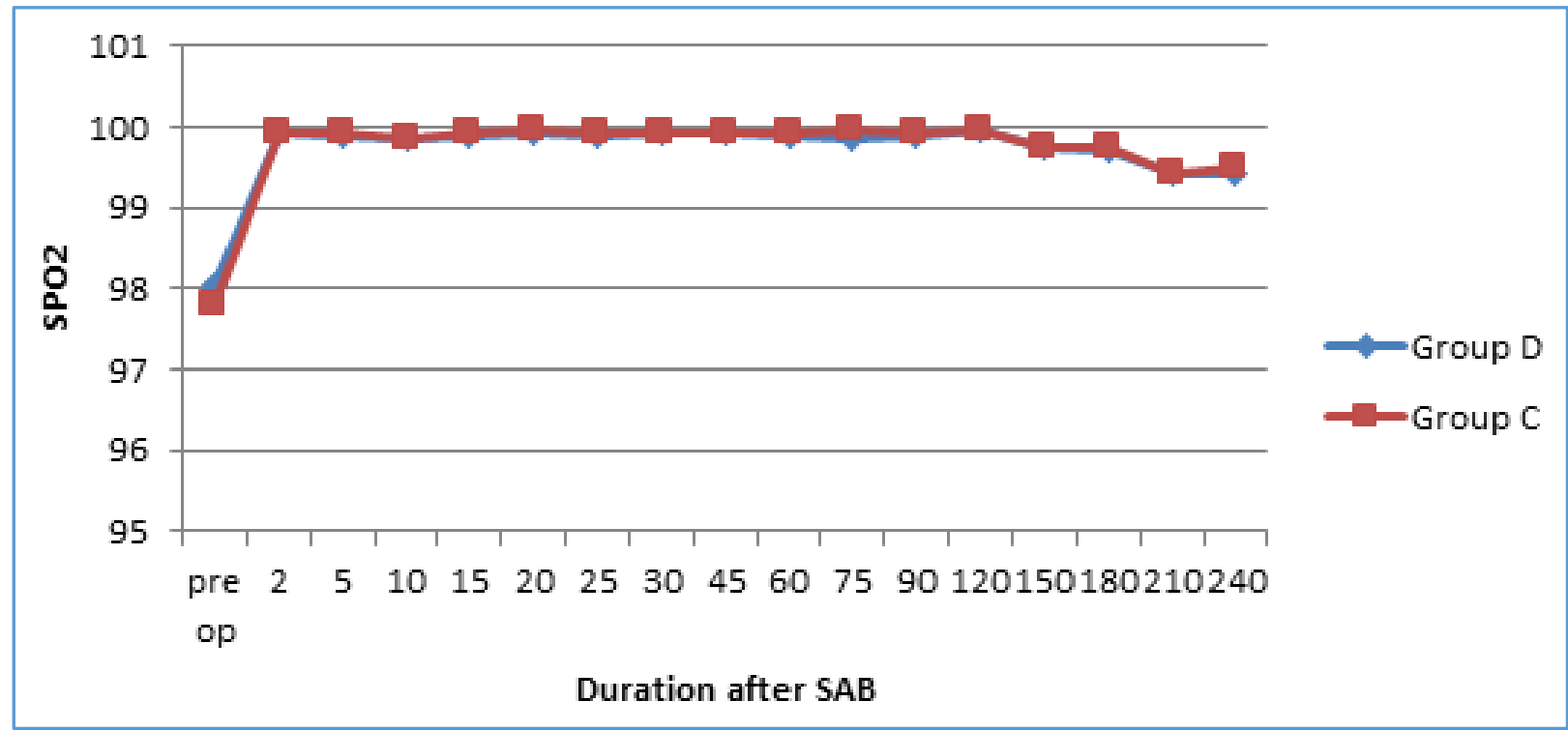

Fig. 4: Line Diagram Comparing the SPO2 in Both the Groups

Respiratory Rate: There was no significant difference in the respiratory rates between both the groups during surgery and in the postoperative period as shown in Figure 5. 


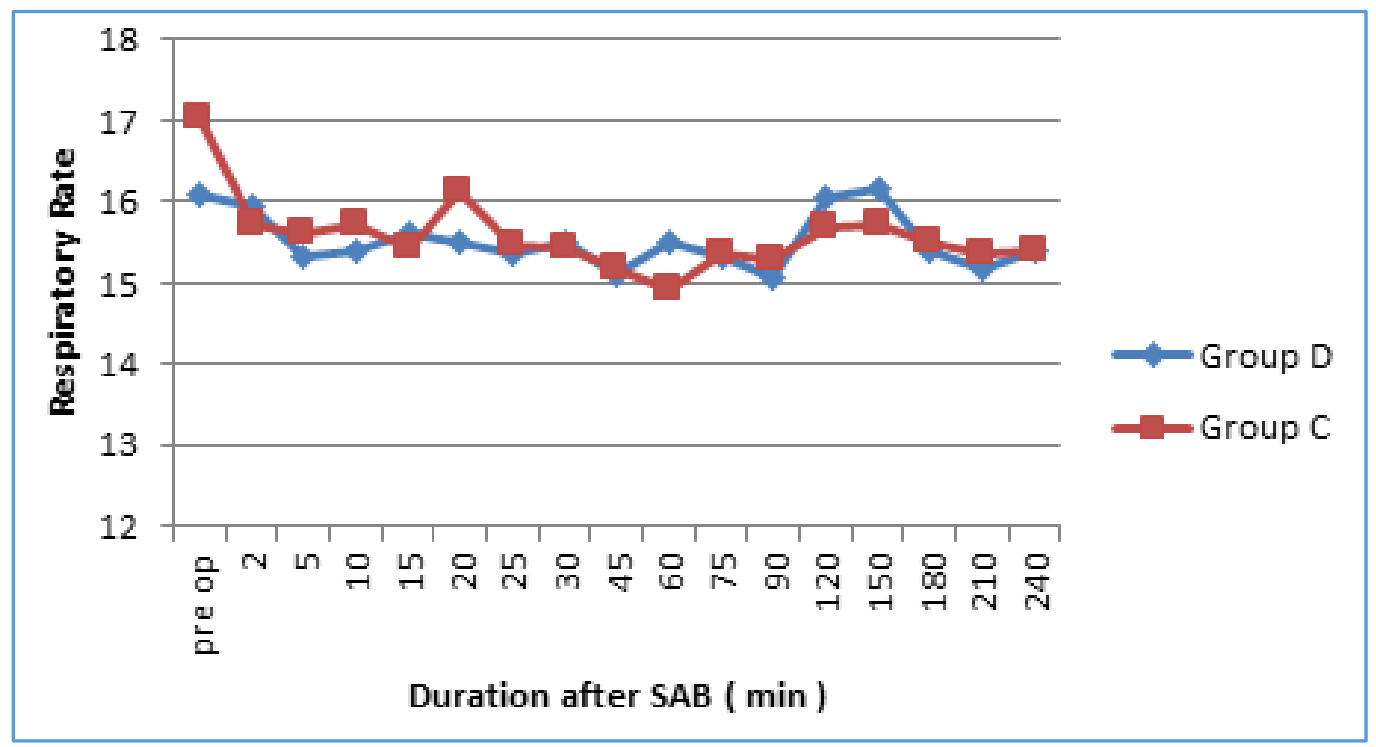

Fig. 5: Line Diagram Comparing the Respiratory Rate in Both the Groups

Ramsay Sedation Score: Ramsay sedation scores were significantly higher in group D (4.56 \pm 0.5$)$ as compared to group C (Mean 2) (p value $<0.0001$ ).

Ramsay sedation scores are summarized in Fig. 6 and Table 3.

\begin{tabular}{|c|c|c|c|c|}
\hline & & \multicolumn{2}{|c|}{$\begin{array}{c}\text { Ramsay Sedation Scores } \\
(\text { Mean } \pm \text { SD) }\end{array}$} & \multirow{2}{*}{$P$ value } \\
\hline & & Group D & Group C & \\
\hline \multicolumn{2}{|c|}{ Baseline 0 min } & 2 & 2 & \\
\hline \multirow{10}{*}{$\begin{array}{l}\text { Duration } \\
\text { of SAB }\end{array}$} & 15 mins & $3.28 \pm 0.6$ & 2 & $<0.0001$ \\
\hline & 30 mins & $4.2 \pm 0.6$ & 2 & $<0.0001$ \\
\hline & 45 mins & $4.6 \pm 0.5$ & 2 & $<0.0001$ \\
\hline & 60 mins & $4.6 \pm 0.5$ & 2 & $<0.0001$ \\
\hline & 90 mins & $4.56 \pm 0.5$ & 2 & $<0.0001$ \\
\hline & 120 mins & $4.56 \pm 0.5$ & 2 & $<0.0001$ \\
\hline & 150 mins & $4.12 \pm 0.7$ & 2 & $<0.0001$ \\
\hline & 180 mins & $3.28 \pm 0.6$ & 2 & $<0.0001$ \\
\hline & 210 mins & $2.28 \pm 0.4$ & 2 & $<0.0001$ \\
\hline & 240 mins & $2.08 \pm 0.27$ & 2 & $<0.0001$ \\
\hline \multicolumn{5}{|c|}{ Table 3: Ramsay Sedation Scores in Both the Groups } \\
\hline
\end{tabular}

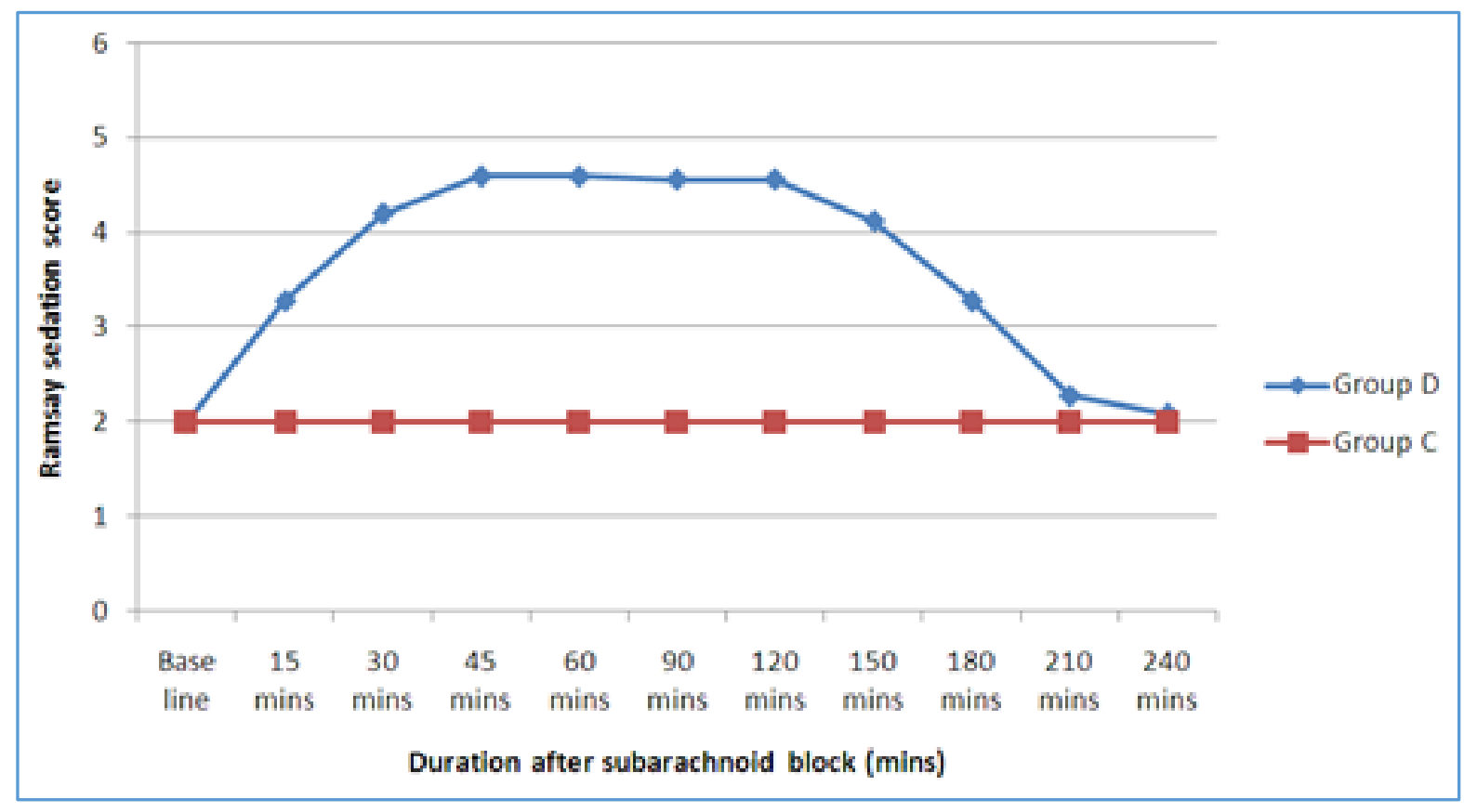

Fig. 6: Line Diagram Comparing the Ramsay Sedation Scores between the 2 Groups 
Postoperative Nausea and Vomiting: Postoperative nausea and vomiting was noted in 1 patient (4\%) in dexmedetomidine group as compared to none $(0 \%)$ in control group ( $\mathrm{p}$ value 0.495).

Sensory Blockade: IV Dexmedetomidine significantly prolongs the sensory blockade of intrathecal bupivacaine.In our study mean time for two dermatomal regression of sensory blockade was significantly prolonged in dexmedetomidine group(128.4 \pm 9.54$)$ as compared to control group $(95.6 \pm 9.61)$ ( $p$ value $<0.001)$. Significant prolongation in mean time for two dermatomal regression of sensory blockade was also reported by others [Kaya et al $52-145 \pm 26$ min v2s $97 \pm 27$ mins $(\mathrm{P}<0.001)$, Tekin et al. ${ }^{9} 14-148.3$ mins vs 122.8 mins ( $\mathrm{P}$ value $<0.001$ ) in dexmedetomidine and control groups respectively].

Similarly, Hong et al., reported that the mean time to twosegment regression was prolonged in dexmedetomidne group [78 mins vs 39 mins for cold, $61 \mathrm{~min}$ vs $41 \mathrm{~min}$ for pinprick for dexmedetomidine group and control group respectively]. Similar results were reported by Elcicek et al. ${ }^{3}$ The duration of sensory blockade i.e., time for regression to S1 dermatome was significantly prolonged in dexmedetomidine group [264.32 $\pm 15.3 \mathrm{~min}]$ compared to control group [164.2 \pm 13.12$]$ ( $P$ value $<0.001$ ) in our study.

Significant prolongation in mean duration of sensory blockade in dexmedetomidine group was also reported by others [Al Mustafa et al. ${ }^{2}-261.5 \pm 34.8 \mathrm{~min}$ vs $165.2 \pm 31.5 \mathrm{~min}$ ( $\mathrm{P}$ value $<0.05)$, Whizar-Lugo et al. ${ }^{10}(208 \pm 43.5 \mathrm{mins}$ vs $137 \pm 121.9$ mins $(P=0.05)$ in dexmedetomidine and control groups respectively].

Motor Blockade: IV Dexmedetomidine significantly prolongs the motor blockade of intrathecal bupivacaine.

The regression time to reach the modified bromage scale 0 was significantly prolonged in dexmedetomidine group $(198.8 \pm 16.9)$ as compared to control group $(135.8 \pm 12.38)$ ( $\mathrm{p}$ value $<0.001$ ).

Delay in motor block regression to Bromage Scale 0 was also reported in previous studies [Al Mustafa et al. ${ }^{5} 199 \pm 42.8$ min in vs138.4 \pm 31.3 min (P value $<0.05)$, Whizar-Lugo et al. ${ }^{10}$ $191 \pm 49.8$ min vs $172 \pm 36.4$ (P value- not significant), Tekin et al. ${ }^{9}$ - 215 mins vs 190.8 mins (P value <0.001) for dexmedetomidine group and control group respectively]. Elcicek et al. $^{8}$ and Hong et al. ${ }^{7}$ also found that complete resolution of motor blockade was significantly prolonged in dexmedetomidine group. But contrary to all the above studies, Kaya et al. ${ }^{8}$ reported no significant prolongation in the duration of motor block in dexmedetomidine group compared to control group.

Effect of Dexmedetomidine on SPO2 and Respiratory Rate: Despite providing good sedation, dexmedetomidine does not cause significant respiratory depression, providing wide safety margins. In present study, there was no significant difference in the respiratory rates between both the groups during surgery and in the post-operative period. There was no significant difference in SPO2 levels between both the groups during surgery and in the postoperative period similar to the study of Al Mustafa et al. ${ }^{2}$

Ramsay Sedation Scores: In our study, intraoperative Ramsay sedation scores were significantly higher in dexmedetomidine group [Mean-4.56 \pm 0.5 ] as compared to control group [Mean-2] (P value $<0.001$. Ramsay sedation score was 2 in all patients in control group and ranged from 2-5 in dexmedetomidine group in the study done by Al Mustafa et al. ${ }^{2}$

In their study the maximum score was 5 in $12 \%$ of patients, 4 in $79 \%$ of patients and 3 in $4 \%$ of patients. The maximum mean score of sedation [3.96 \pm 0.55$]$ was attained 30 min after starting dexmedetomidine infusion. Hong et al. ${ }^{7}$ noted that the median sedation scores during surgery were 4 in the dexmedetomidine group and 2 in the control group $(\mathrm{P}$ value $<0.001$ ). A significantly higher average sedation score in dexmedetomidine group was also reported by others. ${ }^{8}$

Postoperative Nausea and Vomiting: No significant difference in the incidence of post-operative nausea and vomiting was noted between both the groups in the present study [ $4 \%$ vs $0 \%$ in dexmedetomidine and control groups respectively ( $p$ value 0.35 )]. Similar results were reported in previous studies. ${ }^{2,10}$

\section{RESULTS:}

\begin{tabular}{|c|c|c|c|c|}
\hline $\begin{array}{c}\text { Sl. } \\
\text { No. }\end{array}$ & Variables & Gr. C & Gr. D & $\begin{array}{c}\text { P } \\
\text { value }\end{array}$ \\
\hline 1 & $\begin{array}{c}\text { Duration of } \\
\text { segment } \\
\text { regression in } \\
\text { min. }\end{array}$ & $95.6 \pm 9.61$ & $128 \pm 9.54$ & $<0.001$ \\
\hline 2 & $\begin{array}{c}\text { Duration of } \\
\text { Sensory } \\
\text { blockade in } \\
\text { min. }\end{array}$ & $164.2 \pm 13.12$ & $264.32 \pm 15.3$ & $<0.001$ \\
\hline 3 & $\begin{array}{c}\text { Duration of } \\
\text { Motor } \\
\text { blockade in } \\
\text { min. }\end{array}$ & 135.8 & $198.8 \pm 16.9$ & $<0.001$ \\
\hline 4 & $\begin{array}{c}\text { Heart Rate in } \\
\text { beats/min. }\end{array}$ & $73.14 \pm 7.21$ & $64.25 \pm 5.88$ & $<0.001$ \\
\hline 5 & $\begin{array}{c}\text { Requirement } \\
\text { of atropine }\end{array}$ & $4 \%$ & $16 \%$ & 0.003 \\
\hline 6 & $\begin{array}{c}\text { Lowest intra- } \\
\text { operative SBP }\end{array}$ & $92.52 \pm 5.37$ & $96.96 \pm 5.52$ & 0.005 \\
\hline 7 & $\begin{array}{c}\text { Lowest intra- } \\
\text { operative DBP }\end{array}$ & $63.9 \pm 4.2$ & $58.48 \pm 5.97$ & 0.0005 \\
\hline 8 & $\begin{array}{c}\text { Ramsay } \\
\text { sedation score }\end{array}$ & 2 & $4.56 \pm 0.5$ & 0.0001 \\
\hline
\end{tabular}

CONCLUSION: Supplementation of intravenous dexmedetomidine significantly prolongs the duration of sensory and motor block of bupivacaine spinal anaesthesia. Dexmedetomidine causes significant decrease in heart rate, mean arterial/systolic blood pressures. The incidence of bradycardia is significantly high when intravenous dexmedetomidine is used as an adjuvant to bupivacaine spinal anaesthesia.

Dexmedetomidine induced bradycardia is transient and responds to atropine. The changes in blood pressure are without significant clinical impact and hypotension can be easily managed with bolus of IV fluids and mephentermine. All patients reached good sedation levels that enabled their cooperation and better operating condition for the surgeon without significant respiratory depression. 


\section{REFERENCES:}

1. Albright GA. Cardiac arrest following regional anaesthesia with Ethidocaine and Bupivacaine-

Editorial Views. The Journal of Anesthesiology. 1979; 51:285-287.

2. Al-Mustafa MM, Badran IZ, Abu Ali HM, Al-Barazangi BA, Massad IM, Al-Ghanem SM. Intravenous dexmedetomidine prolongs bupivacine spinal analgesia. M.E.J. Anesth, 2009; 20: 225-231.

3. Elcicek K, Tekin M, Kati I. The effects of intravenous dexmedetomidine on spinal hyperbaric ropivacaine anesthesia. J. Anesth, 2010; 24: 544-548.

4. Feldman HS, Arthur GR, Pitkaun M, Hurley R, Ducette AM, Cavino BG. Treatment of acute systemic toxicity after the rapid intravenous injection of Ropivacaine and Bupivacaine in the Conscious dog. Anaesth Analg 1991; 73:373-384.

5. Ganong WF. Review of Medical Physiology. 23rd edition. New York: McGraw-Hill company; 2010. Chapter 34, Circulation through special regions; p. 571.

6. Kanazi GE , Aouad MT, Jabbour-Khoury SI, Al Jazzar MD, Alameddine MM, Al-Yaman R, Bulbul M, Baraka AS. Effects of low dose dexmedetomidine or clonidine on the characteristics of bupivacaine spinal block. Acta Anesthesiol Scand 2006; 50: 222-117.
7. Hong JY, Kim WO, Yoon Y, Choi Y, Kim SH, Kil HK. Effects of intravenous dexmedetomidine on low-dose bupivacaine spinal anaesthesia in elderly patients. Acta Anaesthesiol Scand 2012; 56:382-7.

8. Kaya FN, Yavascaoglu B, Turker G, Yildirim A, Gurbet A, Mogol EB, Ozcan B. Intravenous dexmedetomidine, but not midazolam, prolongs bupivacaine spinal anesthesia. Can J Anaes 2010; 57:39-45.

9. Tekin M, Kati I, Tomak Y, Kisli E. Effect of dexmedetomidine IV on the duration of spinal anesthesia with Prilocaine: a double-blind, prospective study in adult surgical patients. Current Therapeutic Research 2007; 68:313-324.

10. Whizar-Lugo V, Gómez-Ramírez IA, Cisneros-Corral R, Martínez-Gallegos N. Intravenous dexmedetomidine vs. intravenous clonidine to prolong bupivacaine spinal anaesthesia. A double blind study. Anestesia en Mexico 2007;19:143-146.

11. Yazbek-Karam VG, Aouad MA. Perioperative uses of dexmedetomidine. M.E.J. Anesth 2006; 18:1043 -1058. 